\title{
SYSTEMIC DETERMINANTS FOR CHANGES IN ECONOMIC STRUCTURES. THEORETICAL APPROACH
}

\author{
Joanna RYDROWSKA-KURZBAUER \\ Silesian University of Technology, Faculty of Organization and Management, Department of Economics and \\ Informatics, Poland; joanna.rydarowska-kurzbauer@polsl.pl, ORCID: 0000-0001-7024-9088
}

Purpose: The purpose of the article is to present systemic determinants of structural changes in the economy

Design/methodology/approach: The article uses critical literature analysis. The theory of structural changes and system theory was reviewed to reveal the impact of the economic system on changes in the economic structure.

Findings: Owing to the conducted analysis, the relationship between the system and the economic structure was presented. On the one hand, shaping the structure turned out to be strategically important for the entire system. On the other, the structure may depend on broadly understood conditions resulting from the properties of the system itself or its environment. Hence, for the same purposes, the systems may differ in their structure, which will be chosen to apply to the existing determinant. It can therefore be assumed that the system is an important determinant for structural adjustments in the economy.

Originality/value: The literature on the subject, as the main factors of changes in economic structures, primarily reveals: the introduction and diffusion of new technologies and the increase in global trade. The nature of their influence has been extensively described by economists. However, systemic determinants of structural transformations are still hardly documented.

Keywords: Economic structure, economic system, changes in the economic structure.

Category of the paper: Literature review.

\section{Introduction}

The theoretical basis for research on changes in economic structure are the achievements of some branches of economic sciences, in particular the theory of growth and economic development. Hypotheses concerning changes and reasons for their occurrence in the economic structure can also be found in the Polish literature. The regularities of structural changes are explained by the so-called "factorial interpretation method". It consists in the fact that the different configurations of factors are assumed as the causes of these changes. The factors most 
frequently mentioned by economists include: technical progress, development of foreign trade and international cooperation in production, substitution of production factors and types of activity, as well as changes in domestic demand. In the research on the causes of structural changes, very little attention is paid to role and the mechanism of direct impact of systemic solutions on changes in economic structures especially in theory. Therefore, the article attempts to demonstrate the theoretical relationship between structural and systemic changes.

\section{System and structure}

The terms system and structure are used in all the sciences of the world, and their exact meaning depends on the circumstances and place of use. The word structure is derived from the Latin word structura, which means construction. In this sense it is also used in colloquial language. The Polish dictionary gives two definitions of structure as:

1. a whole built in some way from individual specific parts,

2. the arrangement and interrelationship of elements constituting the whole.

The word system, however, comes from a Greek word that means connect, join. To quote the Polish dictionary again, the system is an arrangement of elements having a specific structure and constituting a logically ordered whole. From the cited definitions, a conclusion emerges that the two concepts are strongly connected. When adapted to the economy will they also have similar properties? A review of economic literature reveals both the presence of a dictionary concept of structure and the tendency of economists to reach the achievements of other sciences. Hence, for example, the presence in the economic literature of cybernetic depiction of the economic structure, as well as references to the views of biologists, sociologists, and even linguists. In cybernetics, 'the structure of the system is formed by the elements that make up the system and their ordering, i.e. interconnection' (Kyn, Pelikan, 1967, p. 21). Structure elements are treated as components that may be smaller systems. Each of them has its 'internal structure and consists of lower-order elements' (Kyn, Pelikan, 1967, p. 26). In this way, you can create a hierarchy, or using the term of A. Karpiński, a pyramid of structures (Karpiński, 1986) - from the largest to the smallest. It is assumed that at a given stage of the research, the structure of a given element is no longer penetrated.

Due to the cited definitions, the structure can also be considered in terms of relations between its elements. These relations inform about the existence (or not) of references between the states of the elements and their properties and characteristics (Mynarski et al., 1989). The relations between the elements can be, for example, as pointed out by J. Lisikiewicz, reflected by the relationships between the numbers by which these elements were characterised (Lisikiewicz, 1977). There is then talk of relations of a quantitative type. In addition to quantitative relations, qualitative relations are also taken into account, enabling the study of 
both the utility and effectiveness of the structure. However, the structure in the economic sense 'requires a broader than just cybernetic approach' (Karpiński, 1986). This is due to the fact that cybernetics in particular examines how the elements of the system function, emphasising the concept of the whole. However, in order to properly understand the concept of structure in the economic sense, you must take all the components in its semantic field. These components the whole, elements, relations - depicted together, simultaneously and equally give the structure, according to D. Kempny, a separate meaning (Kempny, 1991). The economic structure is usually defined as the relationship between the elements - components of the economy - and the whole, i.e. the economy - also called the system - and the mutual relations between individual elements (Kempny, 1991). Although this definition does not deviate from the dictionary understanding of structure, B. Brock-Palacz notes that it does not take into account an important element (Brock-Palacz, 1997). Namely, it omits the aspect of the number of individual elements of the economic structure and their ordering. The merits of this allegation are obvious because, as revealed in the economic literature, economic reality consists of many wholes, each of which has its own structure. Hence the definition, by B. Wyżnikiewicz, of the economic structure as a set of interconnected partial structures of elements of the economy (Wyżnikiewicz, 1987). In another definition, the same author listed what should be understood by the elements of the economic structure. He defined the economic structure as 'overall connections between and within elements of the national economy: production (manufacturing and division), production factors and economic units'. According to another definition, presented by P. Sulmicki, the elements of the structure are all economic facts (phenomena), and the relationships that occur between them are the economic structure (Sulmicki, 1981). In the literature, the concept of structure is also defined as 'the type, function and quantity of parts (elements) of a given system (system, object)' (Karpiński, 1986, p. 15). Whereas for L. Balcerowicz, the economic structure meant the spatial and sectoral distribution of production activity in a given economy (Balcerowicz, 1997).

According to all the above definitions, the structure should be related to something. This something is called, depending on the author, the arrangement or system. According to A. Schaff, these two terms are connected in a very special way: there is, as he claims, no structure without the system to which it refers, but there is also no system without an appropriate structure (Schaff, 1974). It can be assumed that the structure without connection with the system (arrangement) would be incomprehensible. However, a system whose structure is unknown is defined in system theory as a black box.

General system theory proposes two system descriptions: external and internal. In the external description, emphasis is placed on the feedback between the examined whole and its surroundings. This description is functional because the system's behaviour is determined by its relationship with the surroundings. However, the internal description of the system, according to L. Bertalanffy, is structural in nature, i.e. what happens to the system depends on its elements and interrelationships between them (Bertalanffy, 1984). Therefore, 
from a semantic point of view, it is difficult to notice the difference in the understanding of both concepts: structure and system. The origin of the word 'system' from Greek and 'structure' from Latin could have perversely influenced the semantic closeness of both concepts in Polish.

There is an impressive variety of approaches to defining the concept of system in the literature on system research. This term is often used in various meanings, which means that virtually any object can be represented as a system. It would seem that for systemic science (systems theory) - a scientific discipline which dates back to the 20th century - the concept of system is essential. The foundations of general systems theory were formulated by the, already quoted, Austrian biologist theoretician L. von Bertalanffy. Systems are the study subject of this science, regardless of their nature. Using the same concepts, methods and means, you can describe a wide variety of systems belonging to different sciences. On the one hand, this established the methodological foundations of many fields, but on the other hand, many currents and trends developed within the framework of general system theory. This led to significant terminological differences among authors dealing with this issue. Thus, neither in literature nor in colloquial language, this concept was defined in a clear and synthetic way. There is still discussion among scientists, and the definition of the system is constantly evolving depending on the degree of knowledge and verification of system hypotheses. Some authors describe the system in qualitative terms as a complex of interacting elements. Others define this concept as the Cartesian product of two or more sets. A typological analysis of the diversity of meanings of the concept has been undertaken by W. Sadowski (Sadowski, 1978), among others. He exchanged around 40 terms and divided them into three groups. In the first group he included defining the system as certain classes of mathematical models. To the second group, the most numerous because of the number of definitions, he qualified the system explaining the system using the concepts of: elements, relations, couplings, whole, holistic. To the third group he classified the system using the concepts of input, output, information processing, and control.

According to the definition of J. Habr and J. Veprek, the system means a deliberately defined set of elements and couplings between them that together define the properties of the whole (Habr, Veprek, 1976). From this definition it follows that the system is not an absolutely defined object. It is a deliberately highlighted fragment of reality, conventionally, according to the motives that the researcher uses and the criteria and tools that they use to extract it (Urbanowska-Sojkin et al., 2004). By definition, the system is located against the background of the remaining reality, then called the system's surroundings. It exists in the surroundings and thanks to the surroundings. The consequence of this reasoning is that the system can only be fully described by referring to its relationships with the surroundings. This statement refers to the already mentioned external system description used in general systems theory.

By definition, the system is a non-empty set. This means, depending on the author, that it contains at least one or two interdependent elements. These elements are distinguished according to acknowledged criteria as having system features. The selection of elements of the system of their ownership and definition of the relations between them leads to the creation of 
a set with a non-accidental structure. This selection is made on the basis of, among others assessing the suitability of the listed components and their impact on the effectiveness of the system. The selection criterion can be, for example, the scale of these elements and their quality. The system binds these elements with various relations and gives each of them a specific function. The meaning of a given element of the structure cannot be isolated, it is only revealed after taking into account the role played by the given element in the entire system. The result of their impact 'exceeds a simple sum by a synergistic effect' (Gajęcki, 1990, p. 17). The synergy effect is also noticed by J. Wilkin, for whom the system is a relatively separate, ordered whole, having features that are not the features of its components (Wilkin, 1995).

The system as a set of elements has specific features, as indicated by researchers on this subject. The system's features of the set include coherence, ordering its elements and the ability of the system to fulfil a selected function or achieve a set goal (Urbanowska-Sojkin et al., 2004). A system is considered to be consistent, if a change in one of its elements causes changes in another element belonging to it. An element that does not respond to other changes or does not prompt such changes cannot be included in the system. However, ordering the elements of the set means organising them according to a certain principle. This feature reveals the structural nature of the system and refers to the already mentioned internal description of L. Bertalanffy's system. Both features (coherence and ordering of elements) are a necessary condition necessary for the system to fulfil a specific function or achieve a selected goal. Therefore, it can be concluded that the system has a functionally shaped structure. In other words, if the system is to operate efficiently and perform a specific function, its elements and structure cannot be accidental. Hence, due to the earlier cited definition of structure, elements, their states and relationships between them must be selected in an appropriate manner (Urbanowska-Sojkin et al., 2004).

In every system there are also elements that are crucially important to maintaining its durability and development. Therefore, as R. Gajęcki notes, there is a control element. The control takes place by passing impulses to the system that affect its structure and behaviour (Gajęcki, 1990). System behaviour consists in such a change happening in the system that initiates another event in it or in its surroundings. (Gościński, 1990). On the one hand, separating such an important element will be essential for the system, on the other, ignoring such an element may upset the entire theoretical construction of the system, i.e. its structure.

\section{The economic system and changes in the economic structure}

The above theoretical considerations can be used to describe a specific object, which is the national economy. If we accept the economy as a whole composed of elements, then on the one hand it can be described as a system, and on the other its structure can be considered. 
In the previous part of the article it was pointed out that identifying and ordering elements of the economy is tantamount to determining its structure. How can the economy be described as a system? The literature on the subject does not give a clear answer. The relativity of the system elements discussed earlier is noticeable both in the views of individual authors, as well as in the definitions they create. Differences are also evident in views regarding the scope of the isolated system, which is the economy. Below are some proposals for defining the economy selected from the literature.

One of the first Polish economists to deal with systemic issues was L. Balcerowicz (Balcerowicz, 1993). In his work, he used the concept of the economic system, due to the number of its elements, in a narrow and broad perspective. In a broader sense, the author defines the system as 'an extensive whole, which generally includes all relatively stable determinants of economic activity, both material (resources) and intangible (organisations, institutional rules), the activity itself and its results in a broader or narrower form of the understood products, employment, level and dynamics of consumption, forms and intensity of imbalances, etc.' (Balcerowicz, 1993, p. 14). The system in a narrow sense is a set of features of the economy of a given country, including a set of relatively stable, intangible indicators of economic activity and results located in a given country (Balcerowicz, 1993, p. 14). This definition is close to T. Kowalik's understanding of the system. This author described the economic system as the economy of a given country theoretically described (Kowalik, 2000). He also noted that the environment in which this economy operates is not part of the system. Nor is it current economic policy. However, according to this author, the systemic feature is the policy shaping the legal and organisational framework for economic activity.

H. Leipold proposed a broad view of the economic system, including: (1) economic elements, i.e. natural resources, manufactured goods and people in the roles of producers and consumers, (2) economic relations and activities: production, distribution and consumption, and (3) 'economic order', i.e. all legal rules and social norms binding economic processes (Balcerowicz, 1993).

J. Wilkin made a certain synthesis of the notions of economic system existing in the literature and adopted the following definition: 'An economic system is an arrangement of related institutions, directly and indirectly, through which the process of production, exchange and distribution of products and services takes place. The nature of the institution and the ties between them decide on the foundations of the system, which are: a set of goals pursued by the system, the structure and mechanism of the decision-making process, the mechanism of resource allocation and patterns of distribution of created values' (Wilkin, 1995).

The above definitions used the term economic system in the sense of the national economy. A slightly different, probably the widest, view is proposed by R. Gajęcki, who described the national economy as a socio-economic and political system (Gajęcki, 1990). Through this definition, the author suggests that there are three cross-sections of the structure in the economy: social, economic and political. In the social structure, he distinguished classes, layers and 
groups that represent different interests and endeavours to meet their needs. He described the political structure as an arrangement of parties, divisions and factions guided in their activities by a certain ideology. By economic structure, however, he understood the relationships taking place in the sphere of production, distribution, exchange and consumption between producers and consumers. These three structures coexist within one system in a given country, being its separate elements.

One of the most dual descriptions of the economy by J. Kornai in literature (Kornai, 1977) cannot be overlooked. He proposes to consider the economic system as two related subsystems: the real sphere and the sphere of regulation. The first of them included material or other physical processes, such as production, trade together with storage and transport, consumption and investments. On the other hand, the sphere of regulation (which can be understood as a narrow understanding of the economic system) was mainly thought processes of an information nature, for example, gathering, processing and storing information, preparing decisions as well as decisions and their transmission.

The method of solving the research problem depends to a large extent on the understanding of the concept of the economic system. The above definitions reveal that the separate economic system in the narrower sense is a conventional object occurring in many variants. It seems that the legitimacy of such separation appears when mutual relations between individual spheres (economic, social and political) are irrelevant. However, as K. Porwit claims, this does not provide sufficient basis for studying systemic changes (Porwit, 2000). Then it is necessary to extend the framework of the economic system to its 'dynamic version', i.e. including elements of social and political features. Examples of such an extended approach to understanding systemic changes can also be found in the works of A. Wojtyna (Wojtyna, 1997) and W. Morawski (Morawski, 1998).

It can be assumed that the processes taking place in the economic system belong to the previously defined spheres: regulation and real. These spheres, creating subsystems/elements of the economic system, are mutually dependent. Characteristics of the real sphere, as noted by J. Gościeński (Gościeński, 1990), do not reveal the type of system, but what differentiates them is contained in the sphere of regulation. The relations between these spheres are the same as between the controlled object and the controlling object. It seems that there are as many economic systems as there are possibilities to influence the real sphere. The sphere of regulation creates the basic conditions for conducting economic policy, which consequently conditions the 'path' pursued by a given economic system. On the other hand, the economic system determines the shape of the sphere of regulation, defining its scope, field, instrumentation, and often also the goals of activities.

To realise a particular economic system, as noted by T. Kaczmarczyk, appropriate economic policy tools (among which they mentioned the policy of stabilisation, economic growth and foreign trade) are required (Kaczmarczyk, 2004). Legal solutions and economic policy determine the mechanism of resource allocation (determining 'how much market and how many 
countries') and the way of making decisions. Thus, they create conditions more or less conducive to entrepreneurship, innovation, savings, investments and economic dynamics, i.e. they affect the real sphere. The main currents of modern economic thought point to the fundamental importance of corporate behaviour as a driving force of development processes in the economy. Therefore, according to M.E. Porter, a constant inflow of funds is needed for the development of scientific research and development works (Porter, 1990). The existence of an efficient mechanism for converting scientific and technical achievements into new products, technologies and organisational solutions determines the favourable position of the state in the global economy. It can therefore be assumed that 'from the point of view of long-term analysis, the existing structure of the economy is the effect of coupling the system of functioning of the national economy and economic policy' (Kołodko, 1989, p. 23). The overall economic policy determines the quality and speed of microeconomic adjustment and determines the environment for the functioning of economic entities (consumers, producers, employees and institutions). This policy may be subject to change, in which case economic entities must adapt to changed conditions of the surroundings. New legal and economic conditions cause changes at the level of microstructure (individual elements of the structure), which lead to changes in the macrostructure. The resulting changes in the real sphere illustrate changes in the structure of production.

\section{Summary}

The above considerations led authors dealing with this issue to conclude on the importance of the relationship between the structure and degree and level of organisation and efficiency of the system. W. Sadowski emphasised the interdependence of these concepts. He pointed to the 'circular' nature of their terms, resulting from the fact that each of these terms is defined by means of others and serves to refine their meaning (Sadowski, 2000). On the one hand, shaping the structure turns out to be a strategically important procedure for the entire system. On the other, the structure may depend on broadly understood conditions resulting from the properties of the system itself or its environment. Hence, for the same purposes, the systems may differ in their structure, which will be chosen to apply to the existing determinant. In addition, system elements, their properties and relations between them can be exchanged or changed, and in a non-harmonious manner, which leads to the already described structure changes. It can therefore be assumed that the system is an important determinant for structural adjustments in the economy. 


\section{References}

1. Balcerowicz, L. (1993). Systemy gospodarcze. Elementy analizy porównawczej. Warszawa: Monografie i opracowania SGH.

2. Bertalanffy, L. (1984). Ogólna teoria systemów. Podstawy, rozwój zastosowania. Warszawa: PWN.

3. Brocka-Palacz, B. (1997) Dostosowanie strukturalne w gospodarce Niemiec. Implikacje dla Polski. Warszawa: SGH, Kolegium Gospodarki Światowej.

4. Gajęcki, R. (1990). Strategia rozwoju przemystu. Prognoza zmian strukturalnych. Warszawa: PWN.

5. Gościński, J. (1989). Efektywna reforma gospodarcza. Uwarunkowania i mechanizmy ekonomiczne. Warszawa: PWN.

6. Habr, J., Veperek, J. (1976). Systemowa analiza i synteza. Warszawa: PWE.

7. Kaczmarczyk T. (2004). Zasady porzadku w gospodarce rynkowej. Rola państwa. Warszawa: Difin.

8. Karpiński, A. (1986). Restrukturyzacja gospodarki w Polsce i na świecie. Warszawa: PWE.

9. Kempny, D. (1991). Konwersja strukturalna w przemyśle. Katowice: Akademia Ekonomiczna.

10. Kołodko, G.W. (1989). Kryzys, dostosowanie, rozwój. Warszawa: PWE.

11. Kornai, J. (1977). Teoria systemów gospodarczych. Kierunki badań. Warszawa: PWN.

12. Kyn, O., Pelikan, P. (1967). Cybernetyka a ekonomia. Warszawa: PWE.

13. Lisikiewicz, J., Jurek-Stępień, Sosnwska, A. (1990). Wyznaczniki rozwoju współczesnego przemystu.

14. Morawski, W. (1998). Zmiana instytucjonalna. Społeczeństwo. Gospodarka. Polityka. Warszawa: PWN.

15. Mynarski, S. (1989). Elementy teorii systemów i informacji. Kraków: Akademia Ekonomiczna.

16. Porter, M.E. (1990). The Competitive Advantage of Nations. New York: Free Press.

17. Porwit, K. (1998). Warianty ewolucji systemu gospodarczego w Polsce. Ekonomista, 1.

18. Sadowski, W. (1978). Podstawy ogólnej teorii systemów. Analiza logiczno-metodologiczna. Warszawa: PWN.

19. Schaff, A. (1974). Szkice o strukturalizmie. Warszawa: Książka i Wiedza.

20. Sulmicki, P. (1981). Postęp naukowo-techniczny a zmiany $w$ gospodarce światowej. Warszawa: PWE.

21. Urbanowska-Sojkin, E., Banaszyk, P., Witczak, H. (2004). Zarzadzanie strategiczne przedsiębiorstwem. Warszawa: PWE.

22. Wilkin, J. (1995). Jaki kapitalizm, jaka Polska. Warszawa: PWN.

23. Wojtyna, A. (1997). Rozdział w: Dynamika transformacji polskiej gospodarki. M. Belka, W. Trzeciakowski (eds.). Warszawa: Poltex. 